\title{
CLAY MINERALS AND HUMIC SUBSTANCES AS LANDFILL CLOSURE COVERING MATERIAL CONSTITUENTS: FIRST STUDIES
}

\author{
*Juris Burlakovs ${ }^{1}$, Jovita Pilecka ${ }^{2}$, Inga Grinfelde ${ }^{2}$, Ruta Ozola-Davidane ${ }^{1}$ \\ ${ }^{1}$ University of Latvia, Latvia \\ ${ }^{2}$ Latvia University of Life Sciences and Technologies, Latvia \\ *Corresponding author's email: juris@geo-it.lv
}

\begin{abstract}
Soil and groundwater as the leachate may contaminate surrounding watersheds, thus different pollutants from closed dumps and landfills pose significant risks to human health and ecology. Pollution may lead to soil and water degradation however it might be diminished through sustainable dump site closure projects and processual management. Several decades of clays and clay minerals studies lead to modified clay composites concept that is one of the potential promising solutions for building the landfill covering material and serve as capping biocover layer at the same time. As humic substances are constituents of soil organic matter, pollutants can be sorbed on the surfaces of complex molecules. This kind of humic acid-clay mineral composite materials thus might become as low cost building material component - covering material. Construction of such layer are to be performed as a combination of clay-humic composites and landfill mined fine fraction of waste with small amendment of natural soil. Several hypotheses that are already proven has to be mentioned: a) Clay minerals produce composites with humic substances; 2) Clay-humic complexes reduce through sorption both organic and inorganic pollutants; 3) Low risk of toxic byproducts from landfill mined waste fine fraction can be the problem; 4) Such composites mostly would trap toxic contaminants (e.g., pharmaceuticals) found in reworked fine fraction of waste.

The aim of the work is to provide alternative solution for landfill closure by giving theoretical considerations from multidisciplinary knowledge of environmental engineering, chemistry and waste management.
\end{abstract}

Key words: landfill biocover, solid waste fine fraction, leaching, circular economy.

\section{Introduction}

The landfills are systems with pollution and aftercare period that takes a long time. Increasing amount of household and industrial wastes, and landfilling in a business-as-usual way lead to a large number of contaminated sites that are called landfills (Burlakovs et al., 2013; Critto et al., 2006; Prokop, Schamann, \& Edelgaard, 2000). This environmental contamination as a result of anthropogenic activities have direct and indirect toxic effects in an unacceptable amount and concentrations that are known from historical studies and monitoring; however, it should be periodically updated for the use of territorial planning or in case of a change of the land use (Burlakovs, Kasparinskis, \& Klavins, 2012). A special attention should be paid to this pollution in a former dump sites, as in many cases this is most problematic for remediation and situated nearby cities. Priority aspect of the importance to be remediated and re-cultivated in an innovative way is tremendously necessary (Burlakovs, 2014; Burlakovs, 2017; Hogland, 2018).

The aim of the work is to provide alternative solution for landfill closure by giving theoretical considerations from multidisciplinary knowledge of environmental engineering, chemistry and waste management.

Former landfills with mixed household waste can be composed of hazardous waste as well as all other types of waste. Historically all around the world different kinds of municipal, residential and construction waste plus hazardous substances were burried in these places; decades of dumping left unacceptable locations of concentrated threat to environment and human health (Burlakovs, 2008, 2012). Innovative solutions and closure, treatment of such dump sites is of high importance.

Humic substances (HS) is of the most important groups of biomolecules (Stevenson, 1982) and has own unique chemical category. HS has distinct unique properties, and those might be isolated from the organic mass. The most common definition is that 'HS are a general category of naturally occuring, biogenic, heterogenous organic substances that can generally be characterized as being yellow to black in color, of high molecular weight and refractory' (Stevenson, 1994).

Soil remediation at dumps often needs more complicated solution starting from primitive soil excavating and transporting to other waste landfills up to sophisticated techniques of remediation by vitrification and using additives that can be used for the treatment of soil.

Remediation with HS has shown good result for diminishing the content of biologically available copper and lead. Contaminated sandy soils and sandy loam from Ap and E soil horizons transformed metals to biologically unavailable stable form and the result was diminished amount of free exchange cations (Burlakovs \& Vircavs, 2011; Burlakovs et al., 2013).

Clay components and humic acids treatment performed to contaminated soil with heavy metals as model contaminants has been done previously. Remediation with easily available additive materials of natural origin such as clays found all over the world in large amounts and modified with HS might be a 
good solution. HS alone performed good results on treatment of copper (Burlakovs et al., 2016).

Remediation technologies can be divided into: insitu and ex-situ methods (Reddy, Adams, \& Richardson, 1999). Soil amendments is in-situ technology for the revitalization process of polluted soil. Clays and clay minerals and humic acids (HA) are important remediation agents for the immobilization of metals in soils (Dercova et al., 2007; Indianara et al., 2009). Thus, locally available resources as natural clays and organic substances are important in this technology and may be effectively used for the treatment. After general treatment enhanced phytoremediation is welcome to finish the process with environmentally and circular economy friendly solution (Valujeva $e t$ al., 2018).

\section{Materials and Methods}

Metal complexation and its potential in remedial processes

Clays are alkaline porous alumio-silicates (Joshi et al., 2002), negatively charged (Mohamed, 2001), neutralized with cations in the structure sites itself
(Breck, 1974; Mondales, Carland, \& Aplan, 1995). Clay minerals with soil organic matter are of particular interest due to ability to form stable complexes with metal ions (Havelcava et al., 2009).

Metal ion complex formation with its natural ability of metal complexation is of unexplored potential for landfill coverage in future. The strength of the interaction among organic ligands and metals may be modeled as a function of $\mathrm{pH}$ and reactant concentration (Byrne et al., 2011) and experimentally proves usefulness of natural clays and HS as remediation amendment for contaminated soils in dumps.

Metals in the Ap horizon during the time of 4 months have been bound in more stable complexes than at the beginning before the HS amendment a stable fraction has increased for both $\mathrm{Cu}$ and $\mathrm{Pb}$. Already the original soil of Ap horizon has high content of organic matter and adding the HS is increasing the stability of metal complexes even further (Figure 1) ((Burlakovs et al., 2013).

Recalculation of metal ions in the solution as well as the ability of metals to bind with humic acids and clays are calculated according formulas (1) and (2):

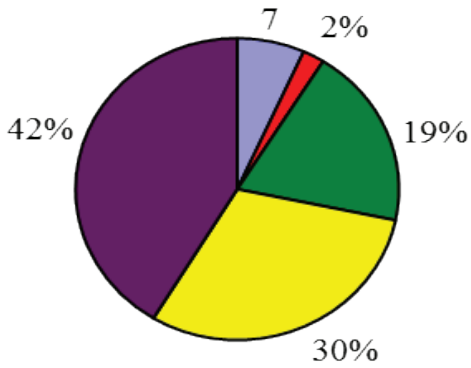

Figure 1. Illustrative example of enhanced copper stability (a) Forms of copper in sandy loam soil with no amendments of HS; (b) Forms of copper sandy loam soil with HS solution amendment of $20 \mathrm{~g} \mathrm{l}^{-1}$.

(Burlakovs et al., 2013).
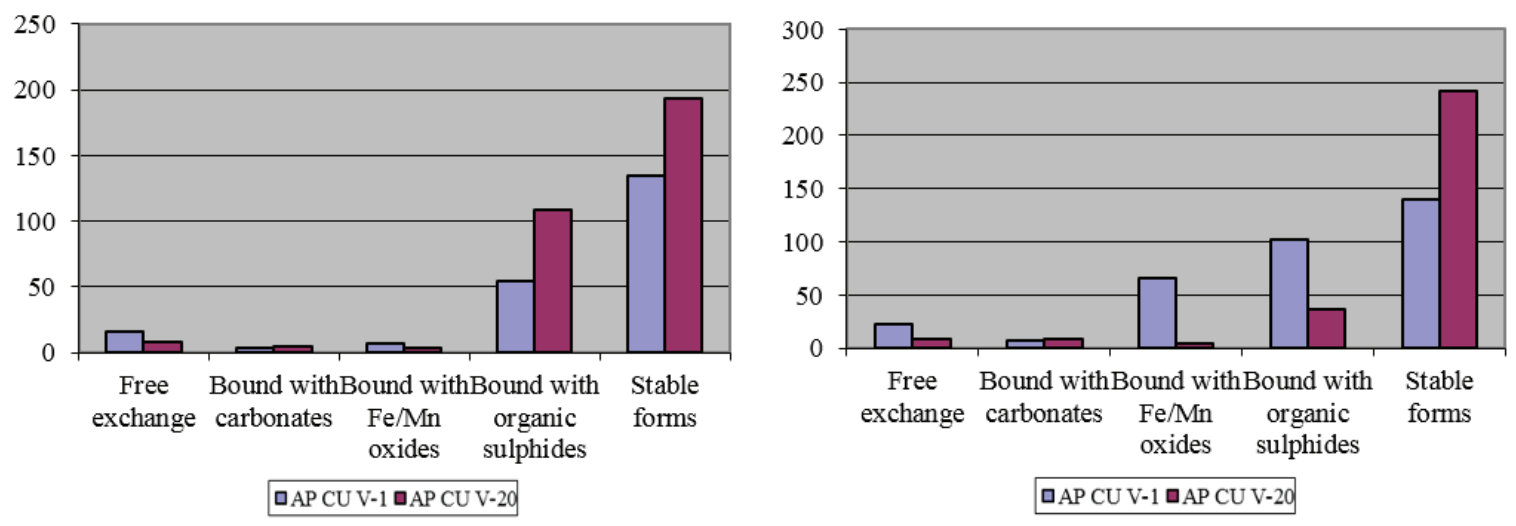

Figure 2. Illustrative example for $\mathrm{HS}$ amendment enhanced $\mathrm{Pb}$ and $\mathrm{Cu}$ stabilization in complexes (a) Amount of free exchange lead $(\mathrm{Pb})$ in sandy soil with no amendment and HS solution of $20 \mathrm{~g} \mathrm{l}^{-1}$; (b) Amount of free exchange copper $(\mathrm{Cu})$ in sandy soil with no amendment and HS solution of $20 \mathrm{~g} \mathrm{l}^{-1}$. 


\section{$C u+H S=C u H S$}

(1)

where the $\mathrm{Cu}$ is the amount of $\mathrm{Cu}^{2+}$ moles in solution and HS - amount of moles of humic acid in the solution, and

$$
K o=\frac{C u H S}{[C u] \cdot(H S-C u H S)}
$$

where $[\mathrm{Cu}]$ - concentration of hydrated $\mathrm{Cu}^{2+}$ in the solution; Ko - stability constant of complex forming; CuHS - amount of moles, which are included in complexes (Bresnahan, Grant, \&Weber, 1978).

It is absolutely clear that clay minerals and HS have done significant enhanced stabilization of $\mathrm{Pb}$ and $\mathrm{Cu}$ in the Ap horizon of sandy soil - it is in biologically less available forms, adding HS is improving formation of stable metal complexes less available for plants. Series of experiments by using HS have shown promising results for diminishing the content of biologically available $\mathrm{Cu}$ and $\mathrm{Pb}$, so we may assume that those ingredients might be of good use for using in landfill closure to stop the migration of heavy metal pollution (Figure 2) (Burlakovs et al., 2013). Contaminated soil exposed to HS transform metals to biologically less available forms meaning that HS can be added in order to make biocover with the use of clay-humic substances composites in biocover material.

\section{Results and Discussions}

Clay minerals and HS composites for pharmaceutical treatment

Natural clay minerals as potential sorbents have received a lot of attention, due to low cost, abundance and interesting properties relevant to treatment procedures of contaminants (Zhang et $a l ., 2015)$. Innovative sorbents may be synthesized by various modification opportunities (Lee \& Tiwari, 2012). For organic pollutants sorption mainly organoclays were popular studied subject (Ozola et al., 2019). Intercalation of various organic compounds is processed in interlayers of double clay layers (Yariv \& Cross, 2002). With some given examples like kaolinite processed in modification with hexadecyltrimethylammonium bromide, may be used to treat chromates, arsenate and nitrates (Li \& Bowman, 2001), while some multi-layered clay minerals with organic modification were good for pesticide removal (Rodríguez-Cruz et al., 2007). The problem is that modified organoclays often may have side effects and are hazardous to environment per sei (Jemeljanova, Ozola, \& Klavins, 2019; Sarkar et al., 2013).

Conversely, humic acid is a non-toxic, naturally occurring organic matter which results from long-term physical, microbial and chemical transformations of organic debris and can be used for clay modification to obtain a sorbent for the removal of organic and inorganic pollutants (Jin et al., 2016; Wang et al., 2018). Humic acid is a chemically heterogeneous compound which contains both hydrophilic and hydrophobic molecules with numerous functional groups - for example, hydroxyl and carboxyl, phenolic and amino groups. Humic acid is mostly negatively charged due to deprotonation of the phenolic and carboxyl groups in aqueous solutions where environment is from weakly acidic to basic (Anirudhan, Suchithra, \& Radhakrishnan, 2009; El-Sayed et al., 2019). Figure 3

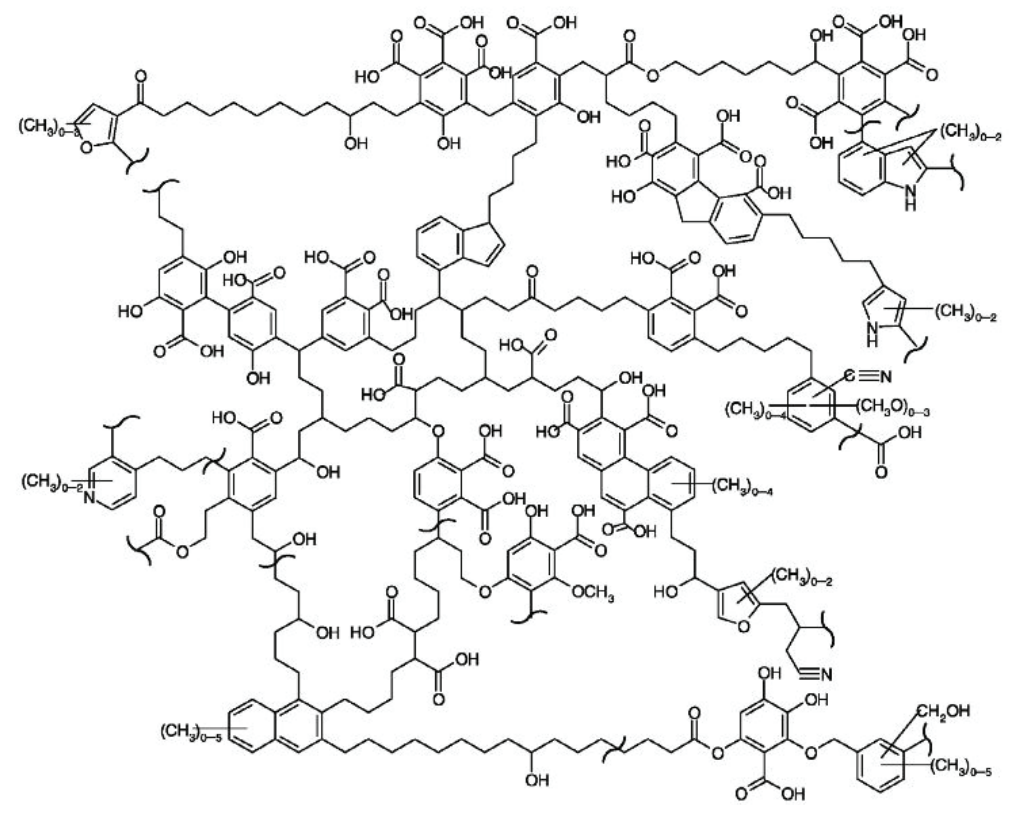

Figure 3. Humic acid structure (Zhu et al., 2018). 


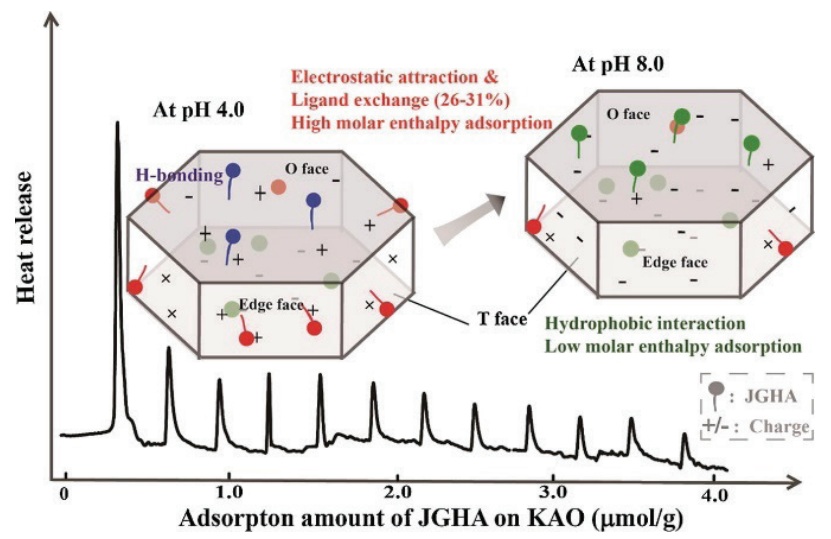

Figure 4. The thermogram and indication of humic acid adsorption sites on kaolinite surface (Chen et al., 2017).

shows the hypothetical structure of humic acid containing all structural components.

Sorption mechanism of humic acid on clay mineral surface includes ligand exchange, cation and water bridging, entropy driven hydrophobic interactions and van der Waals interactions (Chotzen et al., 2016; Feng, A.J. Simpson, \& M.J. Simpson, 2005; Wang et al., 2018). The favourable sorption mechanisms are determined by the nature of humic acid molecules as well as by the properties of the clay mineral surface. Humic acid adsorption on kaolinite mineral mostly occurs by ligand exchange reaction between polar organic functional groups of humic acid and hydroxyl edge surface sites of clay mineral. While humic acid adsorption on smectite type minerals occurs mostly on the large basal surfaces; electrostatic interaction, bridging and hydrogen bonding account for the formation of organic coatings on the clay particles (Chotzen et al., 2016; Feng, A.J. Simpson, \& M.J. Simpson, 2005; Ghosh 2009; Wang et al., 2018).

Also, an important factor that affects adsorption is $\mathrm{pH}$ of environment (Figure 4). For example, at alkaline $\mathrm{pH}$ hydrophobic attraction is the main interaction mechanism between humic acid and kaolinite. This reaction mainly occurs only on the kalinite's hydrophobic basal plane (T-face). At acidic $\mathrm{pH}$ the edge-face and the O-face of kaolinite becomes more positively charged and electrostatic interaction between clay mineral and humic acid is one of main adsorption mechanisms next to ligand exchange (Chen et al., 2017).

There have been numerous publications studying clay minerals and humic acid composites for removal of different pollutants such as heavy metals (Jin et al., 2016), radioactive elements (Hongxia et al., 2016) and dyes (Anirudhan, Suchithra, \& Radhakrishnan, 2009) and phosphorus in wastewater and surface waters (Zamparas et al., 2015).

However, currently crucial is contamination with pharmaceutical products - emerging environmental pollutants widely used as human and veterinary drugs to treat infectious diseases. These chemicals have gained increasing attention in recent years, due to increasing consumption of pharmaceuticals and continuous release into the aquatic environment. Pharmaceuticals enter the water systems through wastewater effluent, sewage sludge, landfill leachate, manure applications or from industries. The main problem is that removal of these compounds during wastewater treatment is presently insufficient, resulting in their occurrence not only in treated wastewater but also in ground water and drinking water. The effect and the fate of pharmaceuticals on the human health and wildlife are still unclear. Though, it has been found these compounds potential to cause aquatic toxicity, genotoxicity, endocrine disruption and development of resistance in pathogenic microbes (Couto, Lange, \& Amaral, 2019; de Oliveira et al., 2019; Dogan et al., 2020; Dordio et al., 2017; Stadlmair et al., 2018).

Recent studies have shown that clay minerals and clay-humic acid composites can be natural, low cost and effective sorbents to remove various pharmaceutical products from environment. For example, montmorillonite has been used to remove pharmaceutical products such as tramadol and doxepine (Thiebault, Guegan, \& Boussafir, 2015); kaolinite to remove ofloxacin ( $\mathrm{Li}, \mathrm{Bi}, \&$ Chen, 2017); and natural clay (mainly consisting from smectite and kaolinite) to remove ibuprofen, naproxen and carbamazepine from aqueous solutions (Khazri et al., 2017). While montmorillonite and humic acid composites have been studied as sorbents for removal of tetracycline, oxytetracycline and chlortetracycline which are broad spectrum antibiotics widely used in animal production. Results confirmed that the sorption of antibiotics significantly increased by the presence of humic acid coating on the clay mineral surface. And adsorption of all antibiotics on montmorillonite-humic acid composite was due to existence of coordination or protonation (or both) between cations of clay and 
oxygen in tetracyclines (Bansal, 2012). Likewise, modification of kaolinite with humic acid significantly improved sorption capacity of carbamazepine and increased pore volume and specific surface area of composite material (Wang et al., 2018). However, there have been studies confirming that raw clay and humic acid are more effective sorbents alone than clay and humic acid composite materials due to absence of sorption sites that are being occupied by humic acid molecules (Pils \& Laird, 2007; Yan, Hu, \& Jing, 2012).

\section{Conclusions}

The landfill closure process has similarities with environmental remediation process; however, there are additional components related whether the capping of contamination includes the need of sorption, such as water of irrigation or leachate recirculation and total produced leachate treatment with innovative materials. Environmental risks related to failed closure of landfills require strong scientific basis of geochemical processes in immobilizing matrix and about pollutants. Innovative closure of landfills by capping with landfill mined fine fraction material mixed with modified clay with humic substances is one of prospective solutions. More studies are needed and modelling elaborated in order to find the right recipe for finding the best constituents to stop leaching of pollution out of the landfill as well as mitigate greenhouse gas emissions through methane degradation.

\section{Acknowledgements}

This study was supported by Project 1.1.1.2/ VIAA/3/19/531 'Innovative technologies for stabilization of landfills - diminishing environmental impact and resources potential in frames of circular economy' and EU ESF Project Nr.8.2.2.0/18/A/010 'Academic Staff Renewal and Continuing Professional Development at the University of Latvia'.

\section{References}

Anirudhan, T.S., Suchithra, P.S., \& Radhakrishnan, P.G. (2009). Synthesis and characterization of humic acid immobilized-polymer/bentonite composites and their ability to adsorb basic dyes from aqueous solutions. Applied Clay Science, 43(3-4), 336-342. DOI: 10.1016/j.clay.2008.09.015.

Bansal, O.P. (2012). Thermodynamics of equilibrium adsorption of antibiotics by clay minerals and humic acidclay complexes. National Academy Science Letters, 35(2), 109-114. DOI: 10.1007/s40009-012-0028-8.

Breck, D.W. (1974). Zeolite molecular sieves: structure, chemistry and use. New York, Wiley.

Bresnahan, W.T., Grant, C.L., \& Weber, J.H. (1978). Stability constants for the complexation of copper II ions with water and soil fulvic acids measured by an ion selective electrode. Anal. Chem., 50 (12), 1675-1679. DOI: $10.1021 / \mathrm{ac} 50034 \mathrm{a} 026$.

Burlakovs, J. (2008). Groundwater sampling for monitoring purposes: Case studies in Latvia. In: Proc. International Multidisciplinary Scientific GeoConference SGEM 2012. Vol. 1. Proc. International Multidisciplinary Scientific GeoConference SGEM 2008 (pp. 687-690).

Burlakovs, J. (2012). Dumps in Latvia: Preliminary research and remediation. In: Proc. International Multidisciplinary Scientific GeoConference SGEM 2012. Vol. 2. Proc. International Multidisciplinary Scientific GeoConference SGEM 2012 (pp. 55-62).

Burlakovs, J., Janovskis, R., Stankevica, K., Hassan, I., \& Lacis, S. (2014). Removal of heavy metals from contaminated soils by electrokinetic remediation. Research for Rural Development, 2, 122-126.

Burlakovs, J., Kaczala, F., Stapkevica, M., Rudovica, V., Orupõld, K., Vincevica-Gaile, Z., Bhatnagar, A., Kriipsalu, M., Hogland, M., Hogland, W., \& Klavins, M. (2016). Mobility of metals and valorization of sorted fine fraction of waste after landfill excavation. Waste \& Biomass Valorization, 7, 593-602. DOI: 10.1007/s12649-016-9478-4.

Burlakovs, J., Kasparinskis, R., \& Klavins, M. (2012). Leaching of contamination from stabilization/ solidification remediated soils of different texture. Environmental \& Climate Technologies, 9 (1), 12-16. DOI: $10.2478 / \mathrm{v} 10145-012-0011-0$.

Burlakovs, J., Klavins, M., Osinska, L., \& Purmalis, O. (2013). The impact of humic substances as remediation agents to the speciation forms of metals in soil. APCBEE Procedia, 5, 192-196. DOI: 10.1016/j. apcbee.2013.05.034.

Burlakovs, J., Kriipsalu, M., Arina, D., Kaczala, F., Shmarin, S., Denafas, G., \& Hogland, W. (2013). Former dump sites and the landfill mining perspectives in Baltic countries and Sweden: GeoConference on Science and Technologies In Geology, Exploration and Mining, SGEM2013. Vol. 1. Proc. International Multidisciplinary Scientific GeoConference SGEM 2013 (pp. 485-492).

Burlakovs, J., Kriipsalu, M., Klavins, M., Bhatnagar, A., Vincevica-Gaile, Z., Stenis, J., Jani, Y., Mykhaylenko, V., Denafas, G., Turkadze, T., Hogland, M., Rudovica, V., Kaczala, F., Møller Rosendal, R., \& Hogland, W. (2017). Paradigms on landfill mining: from dump site scavenging to ecosystem services revitalization. Resources, Conservation \& Recycling, 123, 73-84. DOI: 10.1016/j.resconrec.2016.07.007. 
Burlakovs, J., \& Vircavs, M. (2011). Possible applications of soil remediation technologies in Latvia. Environmental \& Climate Technologies, 13 (7), 46-53. DOI: 10.2478/v10145-011-0027-x.

Byrne, L.A., Hynes, M.J., Connolly, C.D., \& Murphy, R.A. (2011). Analytical determination of apparent stability constants using a copper ion selective electrode. Journal of Inorganic Biochemistry, 105 (12), 1656-1661. DOI: 10.1016/j.jinorgbio.2011.07.016.

Chen, H., Koopal, L.K., Xiong, J., Avena, M., \& Tan, W. (2017). Mechanisms of soil humic acid adsorption onto montmorillonite and kaolinite. Journal of Colloid and Interface Science, 504, 457-467. DOI: 10.1016/j. jcis.2017.05.078.

Chotzen, R.A., Polubesova, T., Chefetz, B., \& Mishael, Y.G. (2016). Adsorption of soil-derived humic acid by seven clay minerals: A systematic study. Clays and Clay Minerals, 64(5), 628-638. DOI: 10.1346/ CCMN.2016.064027.

Couto, C.F., Lange, L.C., \& Amaral, M.C.S. (2019). Occurrence, fate and removal of pharmaceutically active compounds (PhACs) in water and wastewater treatment plants - A review. Journal of Water Process Engineering, 32, 100927. DOI: 10.1016/j.jwpe.2019.100927.

Critto, A., Cantarella, L., Carlon, C., Giove, S., Petrzzelli, G., \& Marcomini, A. (2006). Decision SupportOriented Selection of Remediation Technologies to Rehabilitate Contaminated Sites. Integrated Environmental Assessment and Management, 2 (3), 273-285. DOI: 10.1897/1551-3793(2006)2[273:DS SORT]2.0.CO;2.

de Oliveira, M., Frihling, B.E.F., Velasques, J., Filho, F.J.C.M., Cavalheri, P.S., \& Migliolo L. (2020). Pharmaceuticals residues and xenobiotics contaminants: Occurrence, analytical techniques and sustainable alternatives for wastewater treatment. Science of The Total Environment, 705, 135568. DOI: 10.1016/j. scitotenv.2019.135568.

Dercova, K., Sejakova, Z., Skokanova, M., Barancíková, G., \& Makovnikova, J. (2007). Bioremediation of soil contaminated with pentachlorophenol using humic acids bound on zeolite. Chemosphere, 66 (5), 783-790. DOI: 10.1016/j.chemosphere.2006.06.061.

Dogan, A., Płotka-Wasylka J., Kempińska-Kupczyk, D., Namieśnik, J., \& Kot-Wasik, A. (2020). Detection, identification and determination of chiral pharmaceutical residues in wastewater: Problems and challenges. TrAC Trends in Analytical Chemistry, 122. DOI: 10.1016/j.trac.2019.115710.

Dordio, A.V., Miranda, S., Prates Ramalho, J.P., \& Carvalho, A.J.P. (2017). Mechanisms of removal of three widespread pharmaceuticals by two clay materials. Journal of Hazardous Materials, 323, 575-583. DOI: 10.1016/j.jhazmat.2016.05.091.

El-Sayed, M.E.A., Khalaf, M.M.R., Gibson, D., \& Rice, J.A. (2019). Assessment of clay mineral selectivity for adsorption of aliphatic/aromatic humic acid fraction. Chemical Geology, 511, 21-27. DOI: 10.1016/j. chemgeo.2019.02.034.

Feng, X., Simpson, A.J., \& Simpson, M.J. (2005). Chemical and mineralogical controls on humic acid sorption to clay mineral surfaces. Organic Geochemistry, 36(11), 1553-1566. DOI: 10.1016/j. orggeochem.2005.06.008.

Ghosh, S., Wang, Z.Y., Kang, S., Bhowmik, P.C., \& Xing, B.S. (2009). Sorption and Fractionation of a Peat Derived Humic Acid by Kaolinite, Montmorillonite, and Goethite. Pedosphere, 19 (1), 21-30. DOI: 10.1016/S1002-0160(08)60080-6.

Havelcava, M., Mizera, J., Sýkorová, I., \& Pekař, M. (2009). Sorption of metal ions on lignite and the derived humic substances. J. Hazard. Mater. 161 (1), 559-564. DOI: 10.1016/j.jhazmat.2008.03.136.

Hogland, M., Arina, D., Kriipsalu, M., Jani, Y., Kaczala, F., Salomão, A.L., Orupõld, K., Pehme, K.M., Rudovica, V., Denafas, G., Burlakovs, J., Vincevica-Gaile, Z., \& Hogland, W. (2018). Remarks on four novel landfill mining case studies in Estonia and Sweden. Journal of Material Cycles \& Waste Management, 20 (2), 1355-1363. DOI: 10.1007/s10163-017-0683-4.

Hongxia, Z., Xiaoyun, W., Honghong, L., Tianshe, T., \&Wangsuo, W. (2016). Adsorption behavior of Th(IV) onto illite: Effect of contact time, $\mathrm{pH}$ value, ionic strength, humic acid and temperature. Applied Clay Science, 127-128, 35-43. DOI: 10.1016/j.clay.2016.03.038.

Indianara, C.O., Maria, A.S.D.B., Edson, A.S., Joao, H.D., Pedro, A.A., \& Osxaldo, C.M.L. (2009). A comparative study for the ion exchange of Fe(III) and $\mathrm{Zn}(\mathrm{II})$ on zeolite NaY. J. Hazard. Mater., 161 (2-3), 1404-1412. DOI: 10.1016/j.jhazmat.2008.04.111.

Jemeljanova, M., Ozola, R., \& Klavins, M. (2019). Physical-chemical properties and possible applications of clay minerals and humic acid composite materials. Agronomy Research, 17(S1), 1023-1032. DOI: 10.15159/AR.19.019. 
Jin, X., Zheng, M., Sarkar, B., Naidu, R., \& Chen, Z. (2016). Characterization of bentonite modified with humic acid for the removal of $\mathrm{Cu}$ (II) and 2,4-dichlorophenol from aqueous solution. Applied Clay Science, 134, 89-94. DOI: 10.1016/j.clay.2016.09.036.

Joshi, U.D., Joshi, P.N., Tamhankar, S.S., Joshi, V.P., Idage, B.B., Joshi, V.V., \& Shiraljar, V.P. (2002). Influence of the size of extra framework monovalent cations in X-types zeolite on their thermal behaviour. Thermochim. Acta, 387 (2), 121-130. DOI: 10.1016/S0040-6031(01)00840-1.

Khazri, H., Ghorbel-Abid, I., Kalfat, R., \& Trabelsi-Ayadi, M. (2017). Removal of ibuprofen, naproxen and carbamazepine in aqueous solution onto natural clay: equilibrium, kinetics, and thermodynamic study. Appl Water Sci., 7, 3031-3040). DOI: 10.1007/s13201-016-0414-3.

Lee, S.M., \& Tiwari, D. (2012). Organo and inorgano-organo-modified clays in the remediation of aqueous solutions: An overview. Applied Clay Science, 59-60, 84-102. DOI: 10.1016/j.clay.2012.02.006.

Li, Y., Bi, E., \& Chen, H. (2017). Sorption Behavior of Ofloxacin to Kaolinite: Effects of pH, Ionic Strength, and Cu(II). Water Air Soil Pollut, 228. DOI: 10.1007/s11270-016-3236-x.

Li, Z., \& Bowman, R.S. (2001). Retention of inorganic oxyanions by organo-kaolinite, Water Research, 35(16), 3771-3776. DOI: 10.1016/S0043-1354(01)00120-8.

Mohamed, M.M. (2001). Heat capacities, phase transitions and structural properties of cation-exchanged H-mordenite zeolites. Thermochim. Acta., 372 (1-2), 75-83. DOI: 10.1016/S0040-6031(01)00433-6.

Mondales, K.D., Carland, R.M., \& Aplan, F.F. (1995). The comparative ion exchange capacities of natural sedimentary and synthetic zeolites. Miner. Eng., 8 (4-5), 535-548. DOI: 10.1016/0892-6875(95)00015-I.

Ozola, R., Krauklis, A., Burlakovs, J., Klavins, M., Vincevica-Gaile, Z., \& Hogland, W. (2019). SurfactantModified Clay Sorbents for the Removal of p-nitrophenol. Clays and Clay Minerals, 67 (2), $132-142$. DOI: $10.1007 / \mathrm{s} 42860-019-00015-2$.

Pils, J.R.V., \& Laird, D.A. (2007). Sorption of tetracycline and chlortetracycline on K-and Ca-saturated soil clays, humic substances, and clay - humic complexes. Environmental Science \& Technology, 41 (6), 1928-1933. DOI: 10.1021/es062316y.

Prokop, G., Schamann, M., \& Edelgaard, I. (2000). Management of contaminated sites in Western Europe. Topic Report. No 13/1999. European Environment Agency, Copenhagen.

Reddy, K.R., Adams, J.F., \& Richardson, C. (1999). Potential technologies for remediation of Brownfield. Practice Periodical of Hazardous, Toxic, and Radioactive Waste Management, 3 (2), 61-68.

Rodríguez-Cruz, M.S., Sánchez-Martín, M.J., Andrade, M.S., \& Sánchez-Camazano, M. (2007). Modification of clay barriers with a cationic surfactant to improve the retention of pesticides in soils. Journal of Hazardous Materials, 139 (2), 363-372. DOI: 10.1016/j.jhazmat.2006.06.042.

Sarkar, B., Megharaj M., Shanmuganathan, D., \& Naidu, R. (2013). Toxicity of organoclays to microbial processes and earthworm survival in soils. Journal of Hazardous Materials. 261, 793-800. DOI: 10.1016/j. jhazmat.2012.11.061.

Stadlmair, L.F., Letzel, T., Drewes, J.E., \& Grassmann, J. (2018). Enzymes in removal of pharmaceuticals from wastewater: A critical review of challenges, applications and screening methods for their selection. Chemosphere, 205, 649-661. DOI: 10.1016/j.chemosphere.2018.04.142.

Stevenson, F.J. (1982). Humus chemistry, Genesis, composition, reactions. New York: John Wiley \& Sons.

Stevenson, F.J. (1994). Humus chemistry, genesis, composition, reactions. Second edition. New York: John Wiley \& Sons.

Thiebault, T., Guegan, R., \& Boussafir, M. (2015). Adsorption mechanisms of emerging micro-pollutants with a clay mineral: Case of tramadol and doxepine pharmaceutical products. Journal of Colloid and Interface Science, 453, 1-8. DOI: 10.1016/j.jcis.2015.04.029.

Valujeva, K., Burlakovs, J., Grinfelde, I., Pilecka, J., Jani, Y., \& Hogland, W. (2018). Phytoremediation as tool for prevention of contaminant flow to hydrological systems. Research for Rural Development, 1, $188-194$. DOI: 10.22616/rrd.24.2018.029.

Wang, F., He, J., He, B., Zhu, X., Qiao, X., \& Peng, L. (2018). Formation process and mechanism of humic acidkaolin complex determined by carbamazepine sorption experiments and various characterization methods. Journal of Environmental Sciences, 69, 251-260. DOI: 10.1016/j.jes.2017.10.020.

Yan, W., Hu, S., \& Jing, C. (2012). Enrofloxacin sorption on smectite clays: effects of pH, cations, and humic acid. Journal of colloid and interface science, 372(1), 141-147. DOI: 10.1016/j.jcis.2012.01.016.

Yariv, S., \& Cross, H. (2002). Organo-Clay Complexes and Interactions (pp. 680). New York, USA, Marcel Dekker. 
Zamparas, M., Drosos, M., Deligiannakis, Y., \& Zacharias, I. (2015). Eutrophication control using a novel bentonite humic-acid composite material Bephos ${ }^{\mathrm{TM}}$. Journal of Environmental Chemical Engineering, 3(4), 3030-3036. DOI: 10.1016/j.jece.2014.12.013.

Zhang, L., Zhang, B., Wu, T., Sun, D., \& Li., Y. (2015). Adsorption behavior and mechanism of chlorophenols onto organoclays in aqueous solution. Colloids and Surfaces A: Physicochemical and Engineering Aspects. 484 (5), 118-129. DOI: 10.1016/j.colsurfa.2015.07.055.

Zhu, Z., Qiao, Y., Wang, N., \& Cao, J. (2018). Decomposition characteristics of humic acid in boiler make-up water in power plants. Applied Thermal Engineering, 128, 1159-1164. DOI: 10.1016/j. applthermaleng.2017.09.096. 